Military Technical College

Kobry El-Kobbah,

Cairo, Egypt

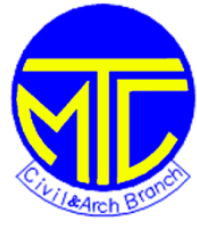

$10^{\text {th }}$ International Conference on

Civil and Architecture Engineering

ICCAE-10-2014

\title{
PERFORMANCE OF STRIP FOOTINGS FOUNDED ON SOFT CLAY LAYER REINFORCED BY STONE COLUMNS
}

\author{
ASMAA M. HASSAN
}

\section{Cairo University}

\section{ABSTRACT}

Stone columns are widely being used for ground improvement. This paper investigates the performance of soft clay reinforced by stone columns with respect to settlement and bearing capacity. A finite element analysis using the software package PLAXIS 2D is carried out. The following parameters are analyzed: the replacement area ratio, the stone column material, footing width, installation technique, and the thickness of the soft clay layer. In addition, a comparison is carried out between the performance of the unreinforced and reinforced soft clay subjected to the same loading condition. Finally, the results are compared with those available in the literature and the advantages of the numerical analysis are highlighted.

\section{INTRODUCTION}

Stone columns are considered one of the most useful ground improvement techniques. Stone columns have been used extensively in weak deposits especially soft clays in order to improve the load bearing capacity, reduce settlement of foundations, and accelerate consolidation settlements. These improvements are achieved due to two factors. First, the large shear strength and stiffness of stone column material compared to the shear strength and stiffness of the native soil. Second, the high permeability of stone column material which allows for reduction in drainage path lengths, thus faster dissipation of excess pore water occurs. (Tan et al., 2008; Zahmatkesh and Choobbasti, 2010).

The stone column technique is a ground improvement process where vertical columns of compacted aggregate are formed through the soil using vibratory probes. The vibrator penetrates to the required depth by vibration and water jetting. Aggregate is then added at the tip of the vibrator and progressive raising and penetration of the 
vibrator results in the aggregate being pushed into the surrounding soil. (Moseley and Kirsch, 2004)

The installation of stone column is found to be accompanied by vibration and horizontal displacement of soil. Therefore, many researches have been conducted to study the effect of generated horizontal displacement of soil during the installation of stone column and post-installation coefficient of earth pressure, $\mathrm{k}^{*}$. Elshazly et.al (2008) presented a relation between the inter-column spacing, S, and $\mathrm{k}^{*}$ in vibroinstallation technique. This relation was inferred from back analysis study based on field test results. Elshazly et.al (2008) concluded that $\mathrm{k}^{*}$ ranges between the at-rest coefficient, $\mathrm{k}_{\mathrm{o}}$ and the passive coefficient $\mathrm{k}_{\mathrm{p}}$.

In addition, many researchers have developed theoretical solutions for estimating bearing capacity and settlement of reinforced foundations by stone columns. Priebe (1976) estimated the settlement of foundation resting on an infinite grid of stone columns based on unit cell concept. In this concept, the settlement improvement factor is derived as a function of area ratio and angle of shearing resistance of column material. Furthermore, Priebe (1995) developed his method by considering the effect of compressibility of the column material and the overburden. In addition, design charts are derived to calculate the settlement of single and strip footing reinforced by a limit number of stone columns.

\section{NUMERICAL MODEL AND MATERIALS}

Finite element analyses are performed using the software PLAXIS 2D version 2.8. In the finite element method a continuum is divided into a number of 15-node triangular elements composing the finite element mesh.

\subsection{Geometry}

In 3D grid, each stone column affects a cylindrical cell around it with a diameter of influence, $D_{e}$ as shown in Figure 1. Balaam and Booker (1981) found that this diameter of influence is directly related to the inter-column spacing, S. (Equation 1)

$$
\mathrm{D}_{\mathrm{e}}=1.13 \mathrm{~S} \text { (square pattern) }
$$

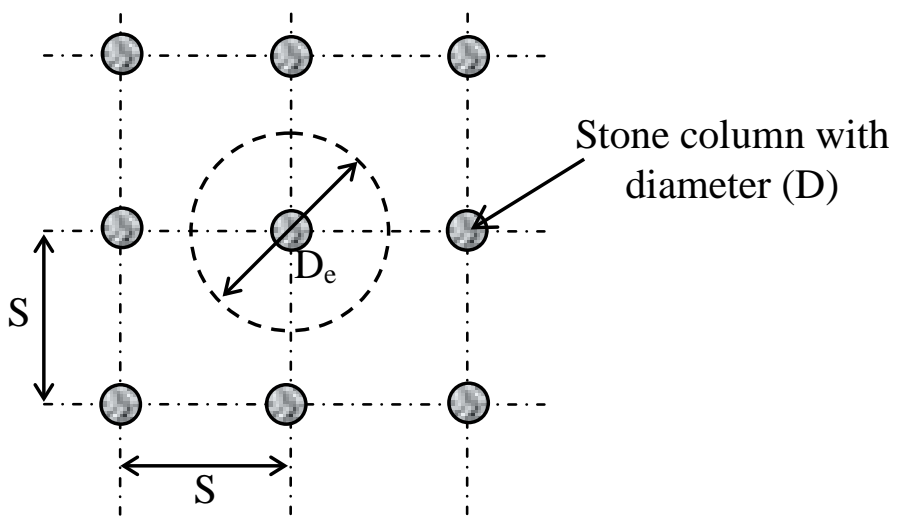


Figure 1. Diameter of Influence for a Stone Column (Square Pattern)

In this research a plain strain condition is considered. Therefore, a 3D stone column grid is represented in $2 \mathrm{D}$ by a series of parallel trenches. Thus, the dimensions of these stone trenches need to be adapted in order to model the behavior correctly. Zahmatkesh and Choobbasti (2010) method to perform this conversion is adopted as shown in Figure 2. In this approach, an equivalent trench with thickness, $t$, is calculated using the stone column diameter, D, and inter-column spacing, S, using Equation 2, whilst, the replacement area ratio is calculated using Equation 3.

$$
\begin{gathered}
\mathrm{t}=\pi \mathrm{D}^{2} / 4 \mathrm{~S} \\
\mathrm{AR}=\mathrm{D}^{2} / \mathrm{D}_{\mathrm{e}}{ }^{2} \times 100
\end{gathered}
$$

Replacement area ratio, AR, of $10 \%, 20 \%$, and $30 \%$ are assumed. These values are selected because for AR less than $10 \%$, no significant improvement is achieved. If AR is larger than $30 \%$, installation difficulties are expected due to close spacing between stone columns.

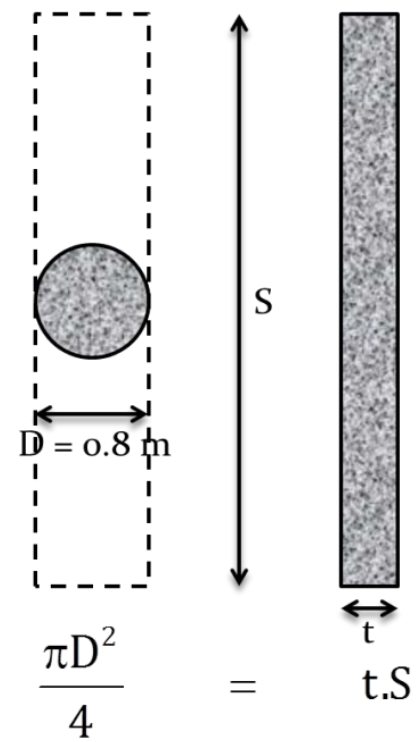

Figure 2. Idealization of Stone Column in Plain Strain Condition

Rigid strip footing is assumed with width B of $1 \mathrm{~m}, 2 \mathrm{~m}$, and $4 \mathrm{~m}$. Thus, both the stone column and soft clay undergo the same value of displacement. An interface is introduced between the stone columns and soft clay. However, no interface is placed under the footing and soil as no slippage is allowed. (Figure 3)

In practice, a platform is placed on the top of soft clay. Therefore, a $30 \mathrm{~cm}$ thick sand layer is placed at top of model. The analysis is carried out on stone column with the diameter, $\mathrm{D}$, of $0.8 \mathrm{~m}$ and height, $\mathrm{L}$, of $8.0 \mathrm{~m}$. The stone columns are usually extended to bedrock or a hard layer, but floating columns may also be installed. Therefore, the soft clay layer is assumed with a depth, H, of $8.0 \mathrm{~m}$ and $16.0 \mathrm{~m}$. (Figure 4) 


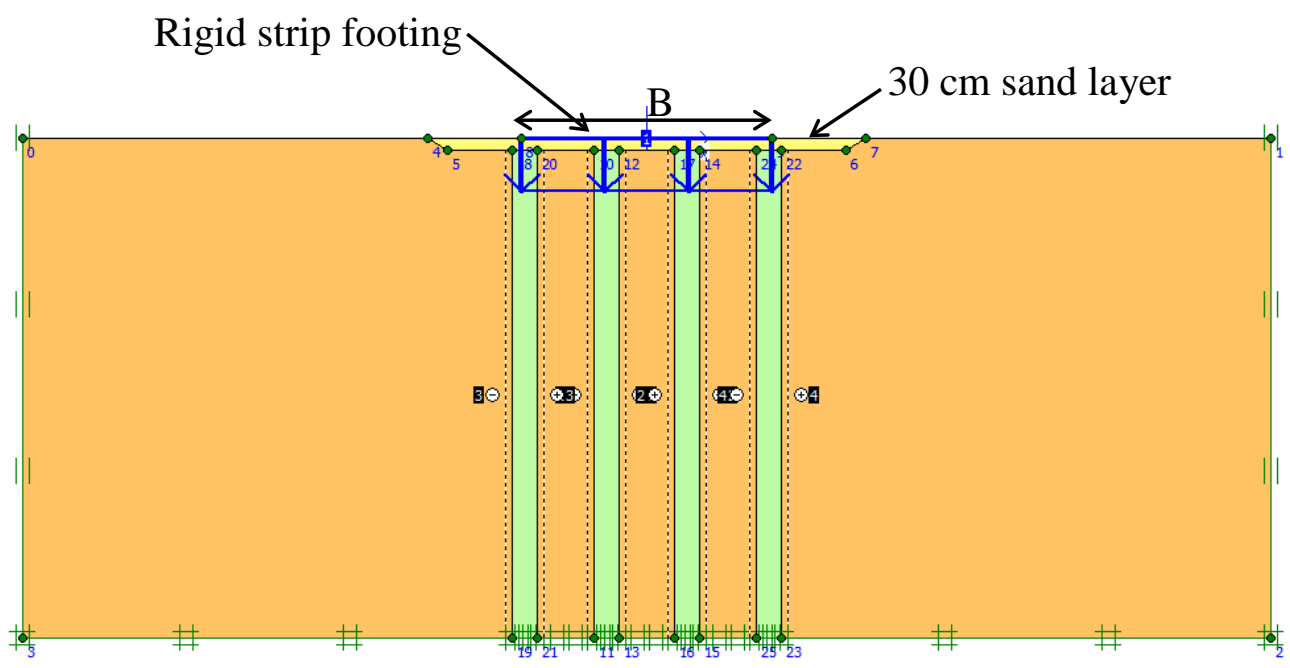

Figure 3. Finite Element Simulation of Stone Column System Beneath A Strip Footing

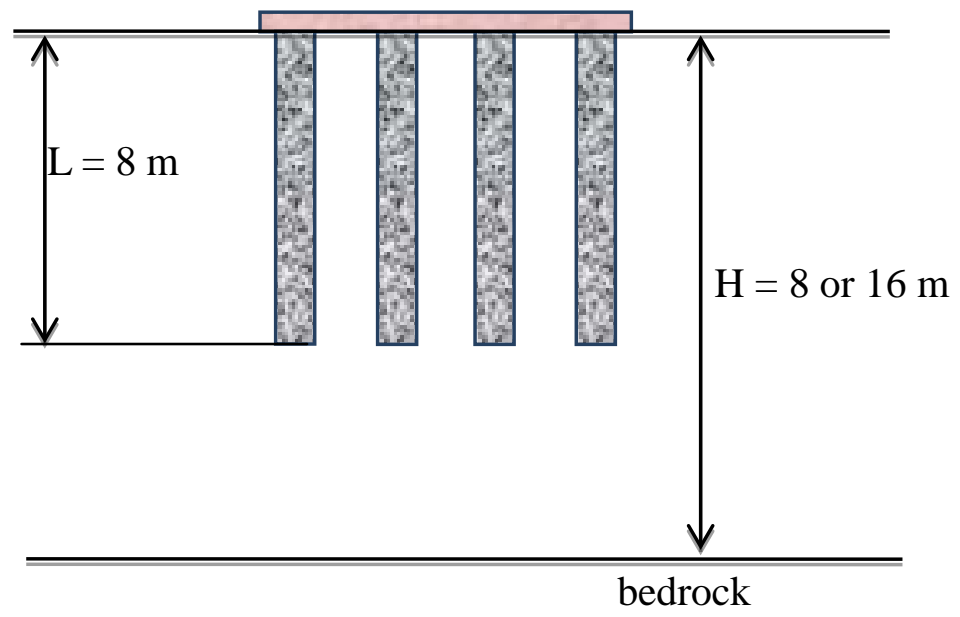

Figure 4. Dimensioning of Stone Column and Soft Clay Layer

\subsection{Materials and Installation}

The properties of soft clay and stone column materials are selected based on values found in the literature. A drained behavior is assumed for all the materials. In this investigation, the constitutive law of Mohr coulomb was used for the stone columns materials and soft soil. The input parameters of Mohr Coulomb model are given in Table 1. The model involves two main parameters, namely the cohesion intercept, c and the angle of shearing resistance, $\phi$. In addition, four parameters namely unit weight, $\gamma$, Young's modulus, E, Poisson's ratio, $v$, and the Dilatancy angle, $\psi$ are needed to calculate the complete $\sigma-\varepsilon$ behavior.

Table 1. Parameters for Soil and Stone Column Materials

\begin{tabular}{|c|c|c|c|c|c|}
\hline Soil & $\gamma$ & $\phi$ & $\psi$ & c & E \\
\hline
\end{tabular}




\begin{tabular}{|c|c|c|c|c|c|c|}
\hline \multicolumn{2}{|c|}{} & $\left(\mathbf{k N} / \mathbf{m}^{\mathbf{3}}\right)$ & $\mathbf{( D e g . )}$ & $\mathbf{( D e g . )}$ & $\mathbf{( k N / \mathbf { m } ^ { 2 } )}$ & $\mathbf{( k N / \mathbf { m } ^ { \mathbf { 2 } } )}$ \\
\hline \multicolumn{2}{|c|}{ Soft Clay } & 15 & 25 & 0 & 0 & 4000 \\
\hline \multirow{2}{*}{$\begin{array}{c}\text { Stone } \\
\text { Column }\end{array}$} & Sand & 17 & 35 & 5 & 0 & 20,000 \\
\cline { 2 - 7 } & Stones & 21 & 40 & 10 & 0 & 100,000 \\
\hline
\end{tabular}

Before the columns are installed, the horizontal component of stress in the ground is given by the equation $\mathrm{k}_{\mathrm{o}} \gamma \mathrm{z}$, where $\mathrm{z}$ is the depth below ground surface and $\mathrm{k}_{\mathrm{o}}$ is the at rest coefficient for the soft clay.

Based on Elshazly et al. (2008), it is found that the soil state of stress is affected by the installation technique of stone column. The vibro-installation technique does not only involve replacement operation but also vibration and horizontal displacement of soil. Consequently, the state of stresses in soft clay increases. This is quantified using the post-installation coefficient of earth pressure, $\mathrm{k}^{*}$. Based on back analysis of field test results, Elshazly et al. (2008) concluded that $\mathrm{k}^{*}$ value ranges between 0.7 and 2.0. This value is found to significantly be affected by inter-column spacing.

\section{RESULTS AND ANALYSES}

A series of two-dimensional finite element analyses have been carried out to study the effect of stone columns installation on the bearing capacity and settlement of strip footing founded on soft clay layer. The results obtained from this investigation with reference to various parameters are presented.

A uniform vertical displacement is prescribed to the model until failure, hence, the footing nodal points are not allowed to move in horizontal directions. Based on results, the stress settlement curves (q-s) are plotted for each studied case as shown in Figure 5. The ultimate bearing capacity for both reinforced and unreinforced soil is defined as the pressure that produces a prescribed value of settlement. Herein, the ultimate bearing capacity for reinforced soft clay, $\mathrm{q}_{\mathrm{u}}$, is defined as the stress corresponding to settlement value equal to $0.05 \mathrm{~B}$. The ultimate bearing stress for unreinforced soft clay is denied as quo. 


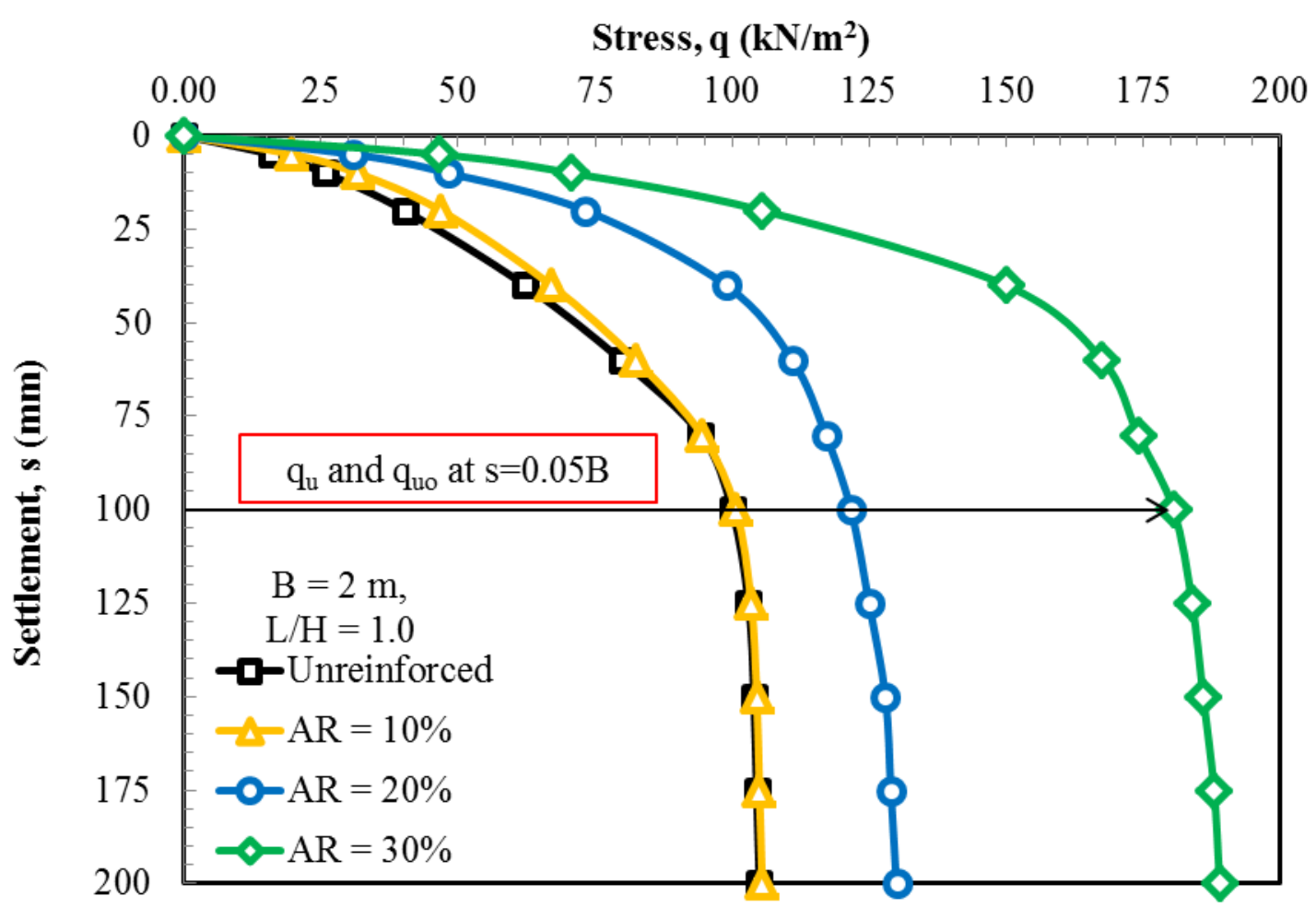

Figure 5. The Stress Settlement Relationship and Determination of Ultimate Bearing Capacity $\left(q_{u}\right)$ for Various Values of AR

\subsection{Effect of Settlement Level}

Figure 6 shows the ratio of bearing stress of reinforced clay to bearing stress of unreinforced clay, $\mathrm{q} / \mathrm{q}_{\mathrm{o}}$ versus the ratio of settlement to footing width, s/B. From this figure, it is clear that as $\mathrm{s} / \mathrm{B}$ increases, $\mathrm{q} / \mathrm{q}_{\mathrm{o}}$ decreases till value of $\mathrm{s} / \mathrm{B}$ of 0.05 . After which, $\mathrm{q} / \mathrm{q}_{\mathrm{o}}$ becomes constant. This may be attributed to the fact that $\mathrm{s} / \mathrm{B}$ equals 0.05 is corresponding to failure occurrence and the load settlement curve becomes almost asymptotic for both reinforced and unreinforced soft clay.

\subsection{Effect of Replacement Area Ratio}

Figures $7 \mathrm{a}$ and $7 \mathrm{~b}$ show the ratios $\mathrm{q}_{\mathrm{u}} / \mathrm{q}_{\mathrm{uo}}$ and $\mathrm{s} / \mathrm{s}_{\mathrm{o}}$ versus $\mathrm{AR}$ at various footing widths. From these figures, it is clear that the ultimate bearing capacity increases and settlement values decreases as AR increases. By further assessment of results, it could also be seen that the rate of improvement in strip footing behavior increases as the value of $A R$ increases. 


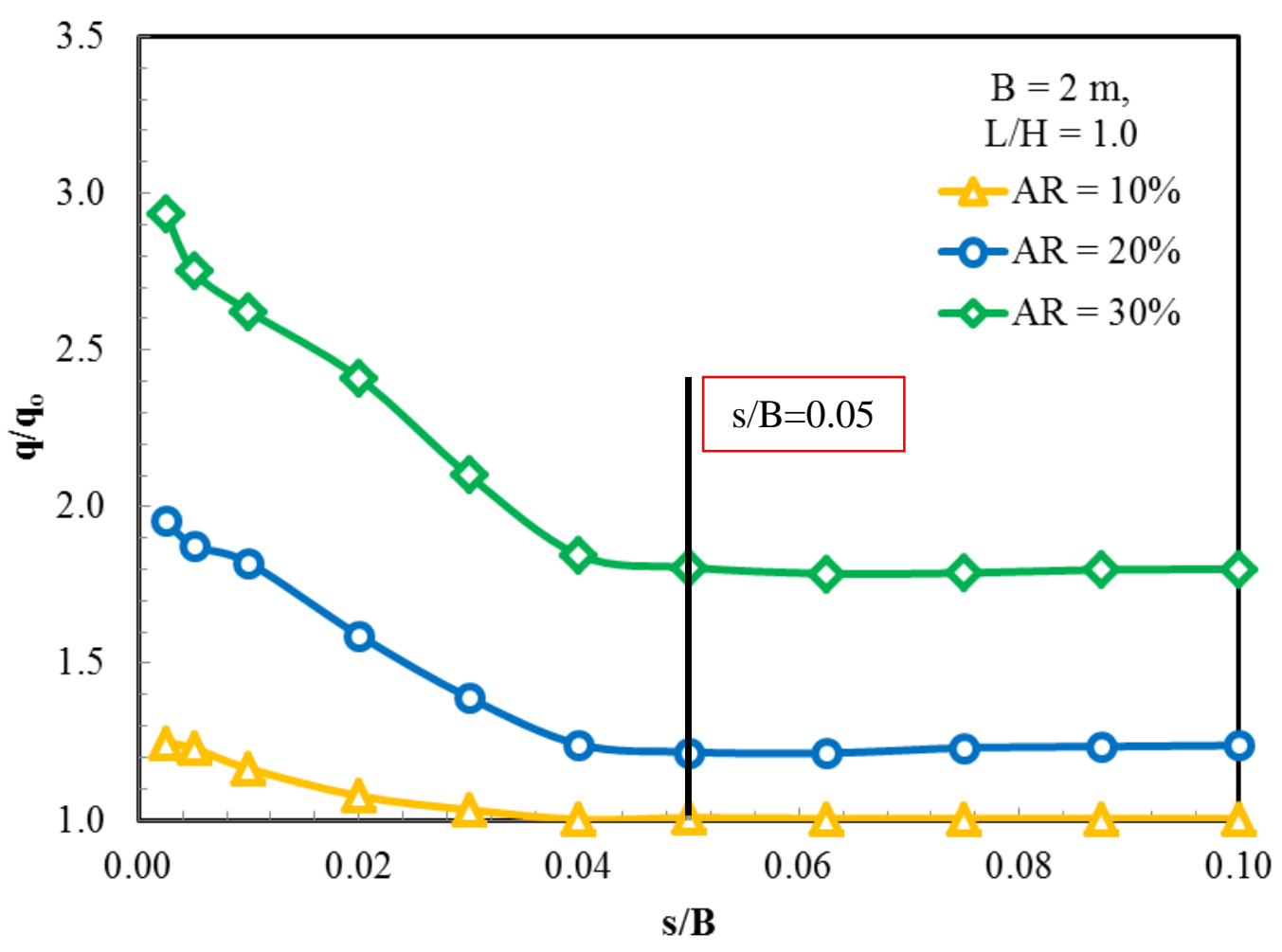

Figure 6. $q / q_{o}$ versus $s / B$ at Various $A R$

\subsection{Effect of Stone Column Material}

Figures $8 \mathrm{a}$ and $8 \mathrm{~b}$ show the ratios $\mathrm{q}_{\mathrm{u}} / \mathrm{q}_{\mathrm{uo}}$ and $\mathrm{s} / \mathrm{s}_{\mathrm{o}}$ versus AR using two types of stone column materials. It is noted that the use of stones as a material of reinforcement leads to better improvement in behavior than using sand. It is also noted that this improvement is more significant as value of AR increases. This is attributed to the fact that stones have higher values of shear strength and stiffness.

\subsection{Soft Clay Layer Thickness}

Figures $9 \mathrm{a}$ and $9 \mathrm{~b}$ show the ratios $\mathrm{q}_{\mathrm{u}} / \mathrm{q}_{\mathrm{uo}}$ and $\mathrm{s} / \mathrm{s}_{\mathrm{o}}$ versus $\mathrm{AR}$ as various $\mathrm{L} / \mathrm{H}$ values. It can be noted that the effect of stone column system resting on a hard layer is more pronounced than a floating stone column system. However, these figures prove that even for deep soft clay layer, the use of stone column system is still an applicable technique for soil improvement. 

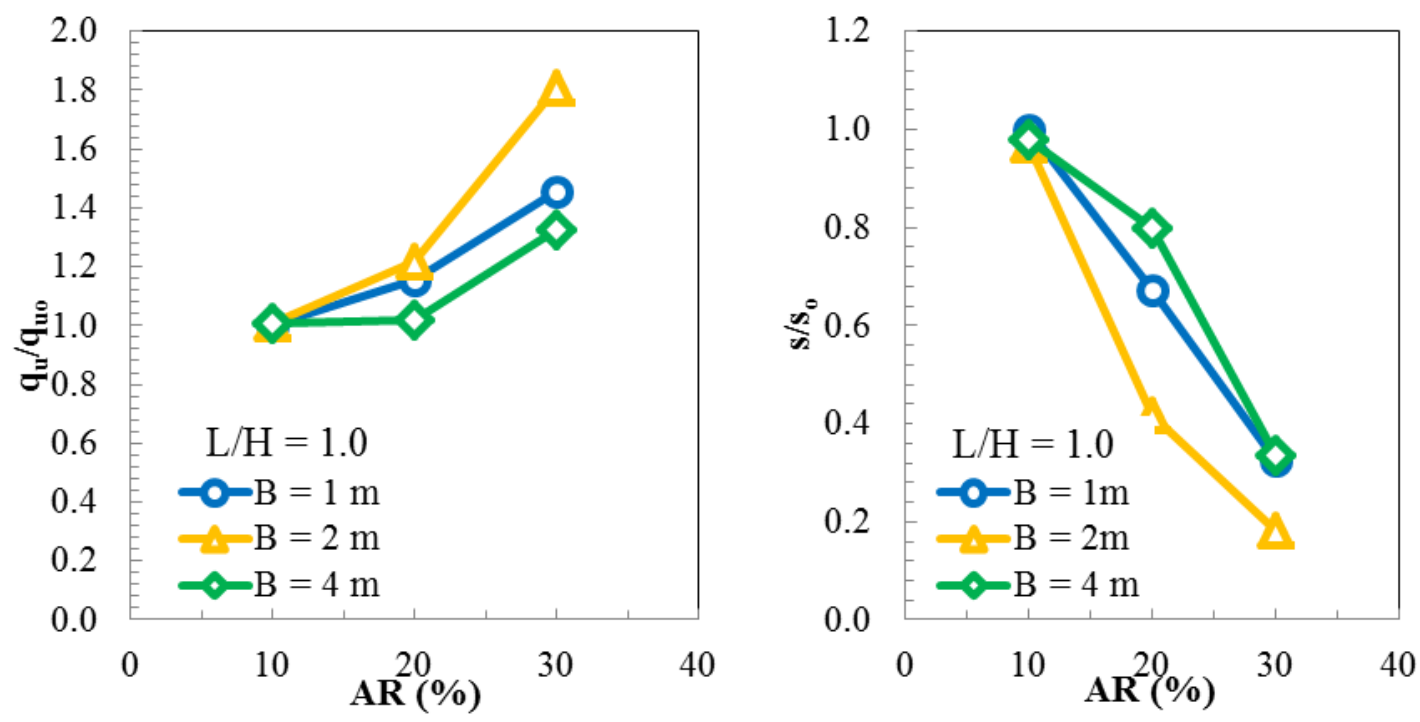

Figure 7. a) $q_{u} / q_{u}$ versus $\left.A R, b\right) s / s_{0}$ versus $A R$ at Various Footing Widths
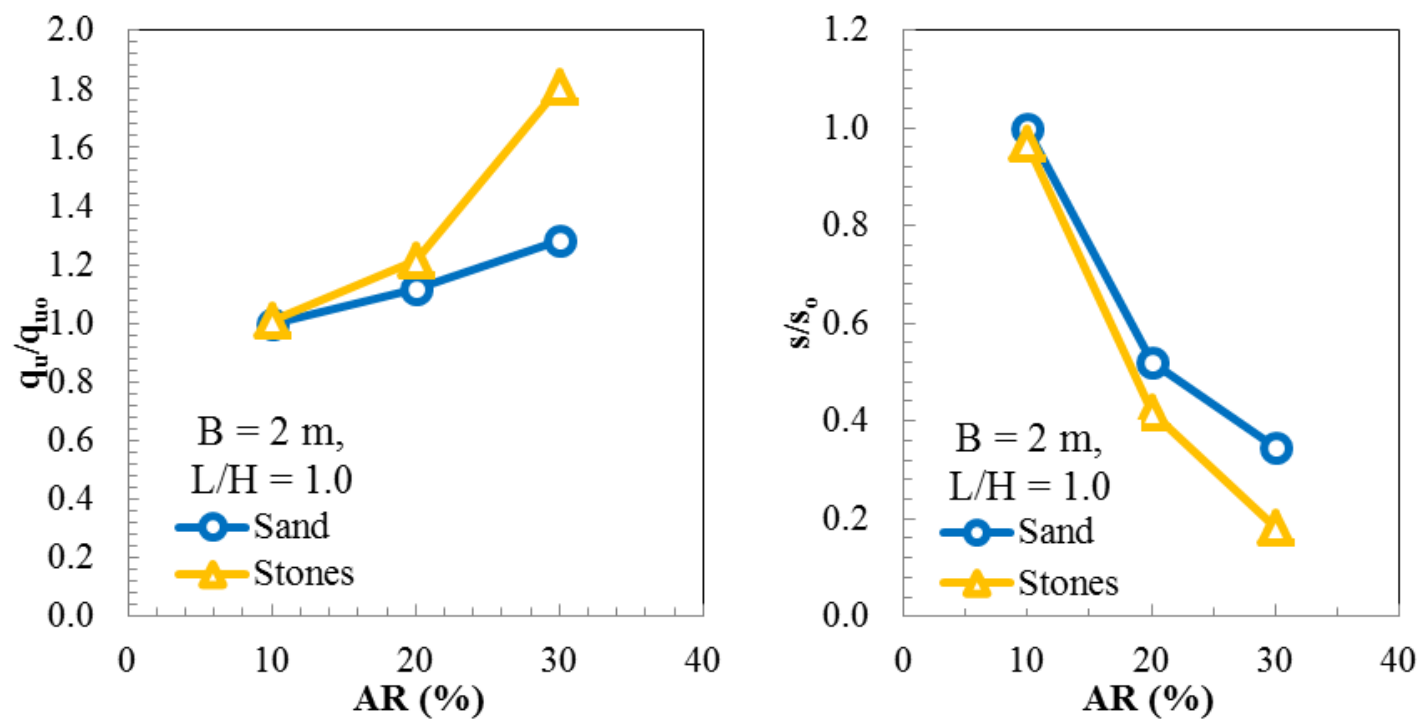

Figure 8. a) $q_{u} / q_{u o}$ versus $\left.A R, b\right) s / s_{0}$ versus $A R$ at Various Stone Column Materials
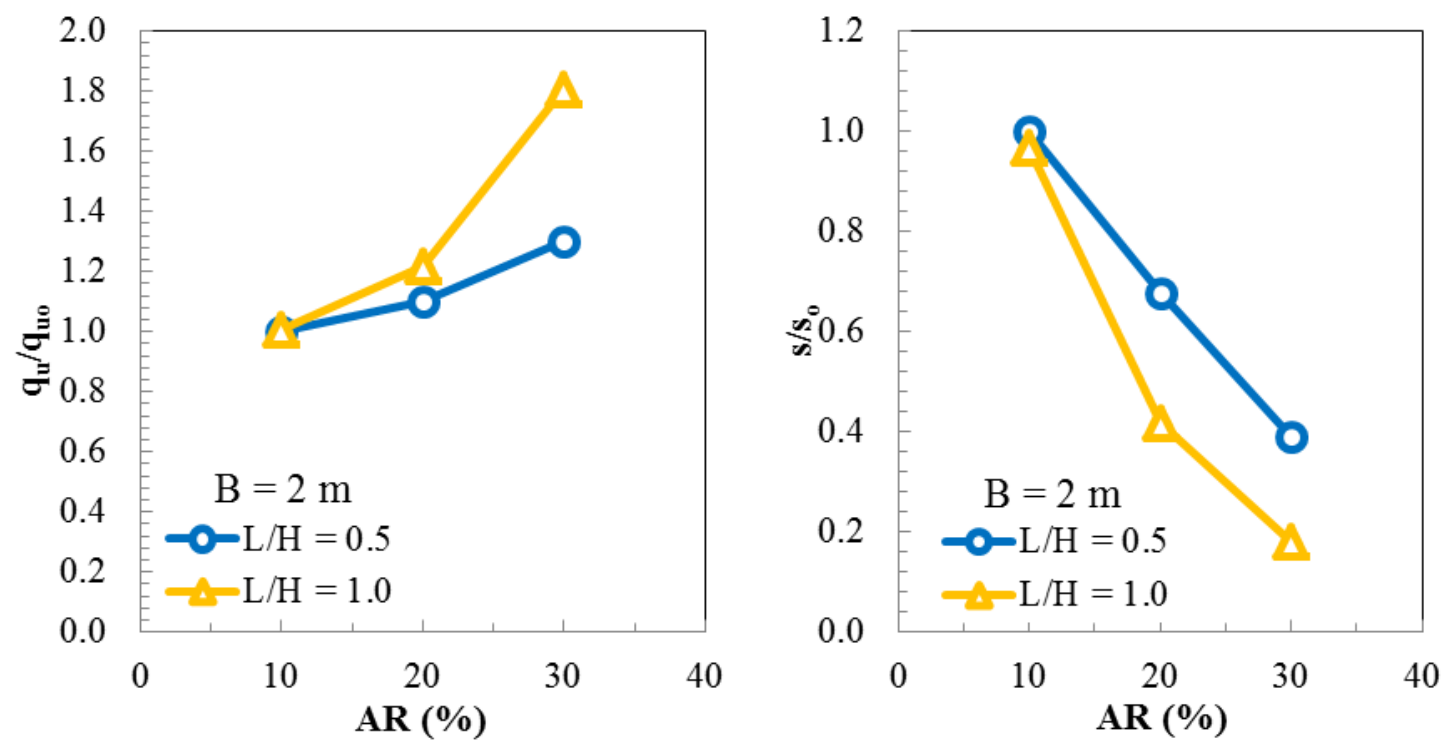
Figure 9. a) $q_{u} / q_{u o}$ versus $\left.A R, b\right) s / s_{0}$ versus $A R$ at Various $L / H$ Values 4.5 Effect of footing width

Figures $10 \mathrm{a}$ and $10 \mathrm{~b}$ present the ratios $\mathrm{q}_{\mathrm{u}} / \mathrm{q}_{\mathrm{uo}}$ and $\mathrm{s} / \mathrm{s}_{\mathrm{o}}$ versus footing width at various values of AR. These figures show that the maximum improvement in behavior occurs at footing width of $2 \mathrm{~m}$. It is also noted that as value of AR increases, the effect of footing width becomes more pronounced.

\subsection{Effect of Installation Technique}

Figures $11 \mathrm{a}$ and $11 \mathrm{~b}$ show the ratios $\mathrm{q} / \mathrm{q}_{\mathrm{o}}$ and $\mathrm{s} / \mathrm{s}_{\mathrm{o}}$ versus $\mathrm{k}^{*} / \mathrm{k}_{\mathrm{o}}$ for a footing width of $2 \mathrm{~m}$. It is noted that the selected state of stress has a significant effect on the degree of improvement of footing behavior. According to Elshazly et al. (2008), for AR of 30\%, $\mathrm{k}^{*}=3 \mathrm{k}_{\mathrm{o}}$ shall be used to consider the effect of installation. If a value of $\mathrm{k}_{\mathrm{o}}$ is adopted, the bearing capacity of the strip footing will be underestimated by $46 \%$ and the expected settlement will be overestimated by $58 \%$.

\subsection{Comparison with literature}

Based on Priebe (1995) work, stress settlement relationship is estimated for unreinforced soft clay and reinforced with AR of 30\%. These relationships are plotted in Figure 12 as well as finite element results. It is clear the Priebe method shows a linear relationship between stress and settlement. In addition failure cannot be identified. On the contrary, finite element model depicts the nonlinear behavior as verified by the results of field loading tests. (Ambily and Gandhi, 2004)

\section{CONCLUSION}

Based on the results obtained in this investigation, the following conclusions can be made related to the influence of stone column installation on behavior of strip footing rested on soft clay layer.

- Installation of stone columns considerably improves the load deformation characteristics of soft clay.

- Stones are more effective than sand to be used as stone column material.

- Area replacement ratio, footing width, stress state, H/L, and stone column material play an important role in affecting the load deformation characteristics of reinforced soft clay.

- Finite element is able to depict the nonlinear behavior of reinforced soft clay and failure in contract to Priebe Method which assumes a linear behavior. 

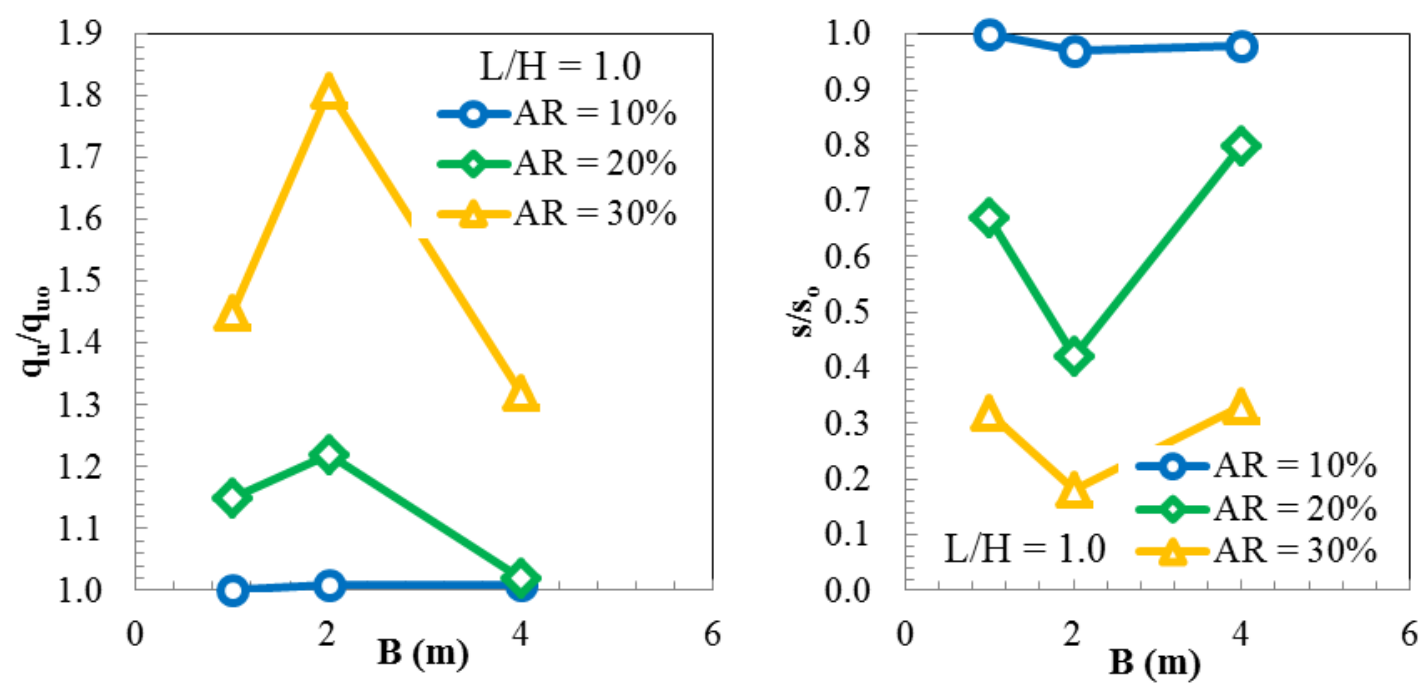

Figure 10. a) $q_{u} / q_{u o}$ versus $B$. b) $s / s_{0}$ versus $B$ at Various AR Values
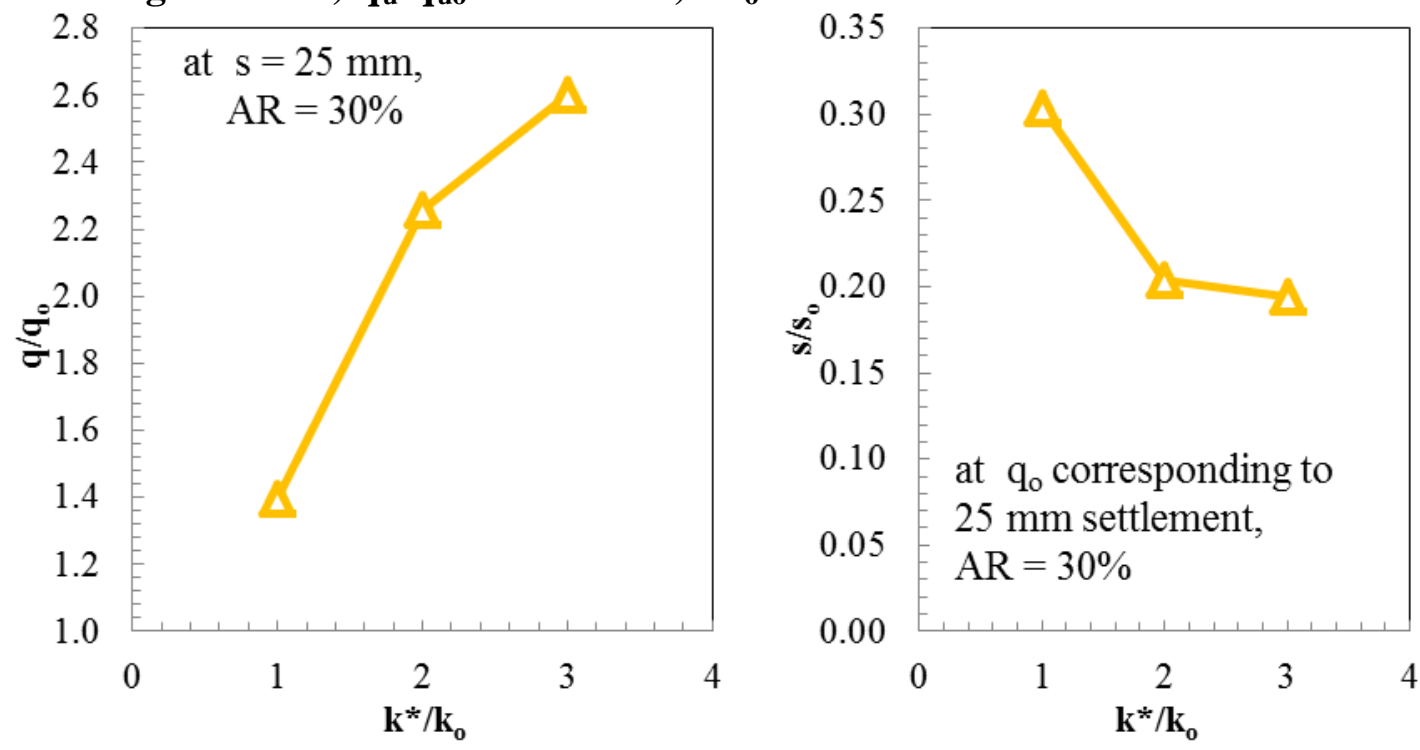

Figure 11. a) $q / q_{0}$ versus $k^{*} / k_{0}$. b) $s / s_{0}$ versus $k^{*} / k_{0}$ at $B=2 m$.

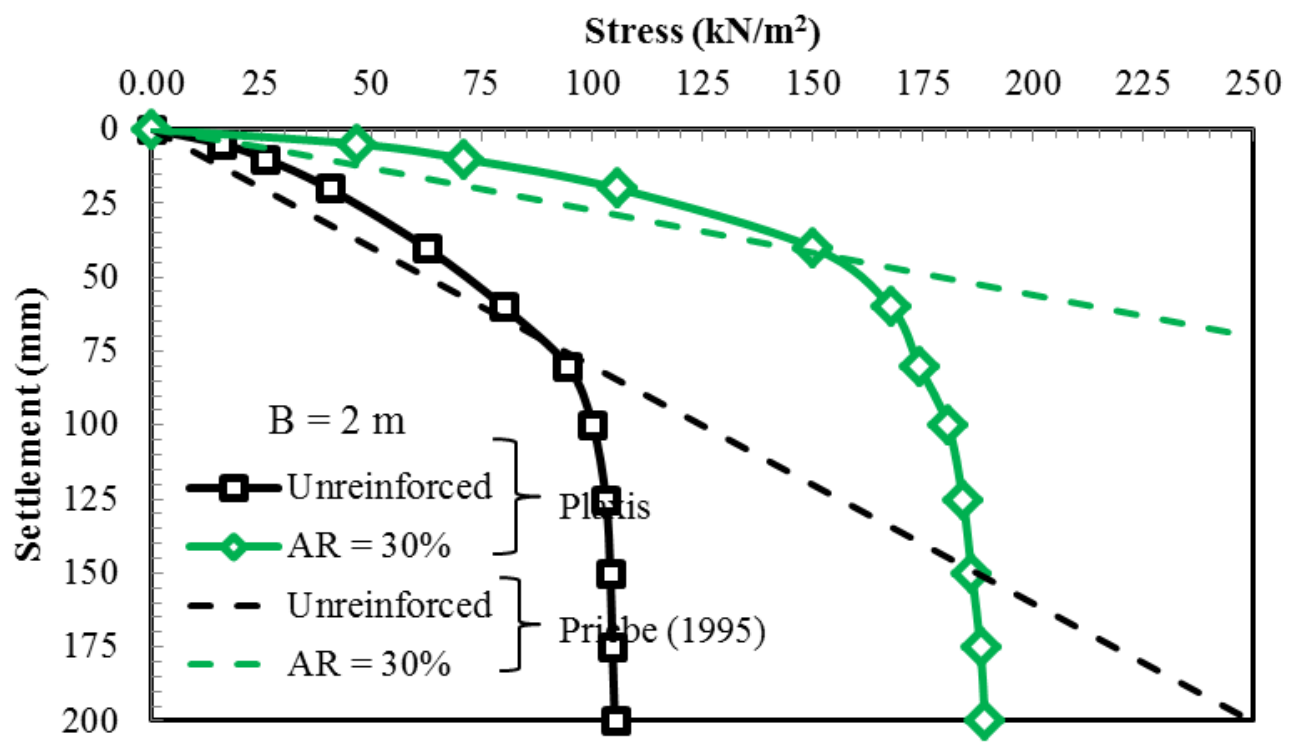


Figure 12. Stress Settlement Relationships Based on Priebe (1995) Method and Finite Element Analysis

\section{REFERENCES}

Ambily, A.P., and Gandhi, S.R., "Experimental and theoretical evaluation of stone column in soft clay”, ICGGE, 2006, pp.201-206.

Balaam, N.P. and Booker, J.R., “Analysis of rigid rafts supported by granular piles”, International Journal for Numerical and Analytical Methods in Geomechanics, vol. 5, 1981, pp. 379-403.

Elshazly, H., Elkasabgy, M., Elleboudy, A., "Effect of Inter-Column Spacing on Soil Stresses due to Vibro-Installed Stone Columns: Interesting Findings”, Journal of Geotechnical and Geological Engineering, vol. 26, 2008, pp.225-236.

Priebe, HJ, "Evaluation of the settlement reduction of a foundation improved by vibro-replacement, Bautechnik, vol. 5, 1976, pp 160-162 (in german).

Priebe, H.J., “The design of vibro replacement”, Ground engineering, 1995, pp.31-37.

Moseley, M.P. and Kirsch, K., “Ground Improvement”, New York: Spon Press, 2004.

Tan, A.S., Tjahyono, S., and Oo, k.k., "Simplified plane-strain modeling of stone column-reinforced ground", Journal of Geotechnical and Geoenvironmental Engineering, vol.134, 2008, pp.185-194.

Zahmatkesh, A. and Choobbasti, A.J., "Investigation of bearing capacity and settlement of strip footing on clay reinforced with stone columns”, Australian Journal of Basic and Applied Sciences, vol.4, 2010, pp.3658-3668. 